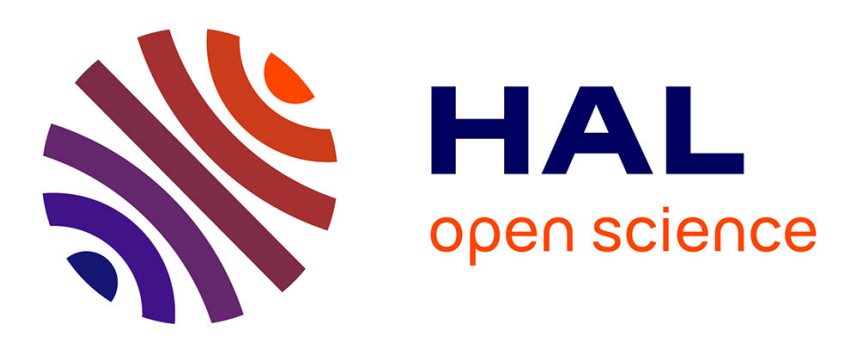

\title{
Identification of proteins binding the native tubulin dimer.
}

Vincent Gache, Mathilde Louwagie, Jérôme Garin, Nicolas Caudron, Laurence Lafanechere, Odile Valiron

\section{- To cite this version:}

Vincent Gache, Mathilde Louwagie, Jérôme Garin, Nicolas Caudron, Laurence Lafanechere, et al.. Identification of proteins binding the native tubulin dimer.. Biochemical and Biophysical Research Communications, 2005, 327 (1), pp.35-42. 10.1016/j.bbrc.2004.11.138 . inserm-00380209

\section{HAL Id: inserm-00380209 https://www.hal.inserm.fr/inserm-00380209}

Submitted on 7 May 2009

HAL is a multi-disciplinary open access archive for the deposit and dissemination of scientific research documents, whether they are published or not. The documents may come from teaching and research institutions in France or abroad, or from public or private research centers.
L'archive ouverte pluridisciplinaire HAL, est destinée au dépôt et à la diffusion de documents scientifiques de niveau recherche, publiés ou non, émanant des établissements d'enseignement et de recherche français ou étrangers, des laboratoires publics ou privés. 
Identification of proteins binding the native tubulin dimer

Vincent GACHE ${ }^{1}$, Mathilde LOUWAGIE ${ }^{2}$, Jérôme GARIN ${ }^{2}$, Nicolas CAUDRON ${ }^{1}$, Laurence LAFANECHERE ${ }^{1}$, Odile VALIRON ${ }^{1}$

${ }^{1}$ INSERM Unité 366, DRDC/CS, CEA-Grenoble, 17 rue des Martyrs, 38054 Grenoble Cedex 9, France

${ }^{2}$ INSERM/CEA/UJF ERM 0201, DRDC/CP, CEA-Grenoble, 17 rue des Martyrs, 38054 Grenoble Cedex 9, France

Corresponding author:

Odile VALIRON

INSERM Unité 366, DRDC/CS, CEA-Grenoble, 17 rue des Martyrs, 38054 Grenoble Cedex 9, France

Tel.: 4-38-78-54-82;

FAX: 4-38-78-50-57

E-mail: ovaliron@cea.fr

Running title: Tubulin dimer binding proteins 


\begin{abstract}
Microtubules play an essential role in eukaryotic cells, where they perform a wide variety of functions. In this paper, we describe the characterization of proteins associated to tubulin dimer in its native form, using affinity chromatography and mass spectrometry. We used an immunoaffinity column with coupled-monoclonal antibody directed against the $\alpha$-tubulin C-terminus. Tubulin was first loaded onto the column, then interphase and mitotic cell lysates were chromatographed. Tubulin-binding proteins were eluted using a peptide mimicking the $\alpha$-tubulin C-terminus. Elution fractions were analyzed by SDS-PAGE, and a total of 14 proteins were identified with high confidence by mass spectrometry. These proteins could be grouped in 4 classes: known tubulin binding proteins, one microtubule associated protein, heat shock proteins and proteins that were not shown previously to bind tubulin dimer or microtubules.
\end{abstract}




\section{Introduction}

Microtubules are hollow cylindrical aggregates, present in the cytoplasm of eukaryotic cells. Microtubules are used by cells for many purposes, being vitally involved in cell motility and division, in organelle transport, and in cell morphology and organization. Microtubule dynamics are regulated by many proteins, whose list has been growing over the past years [1]. Most of them regulate microtubule dynamics by direct binding onto microtubules.

However some tubulin-binding proteins bind preferentially to free tubulin dimers compared to polymerized tubulin. Three of them, stathmin, MINUS and cofactor D inhibit microtubule assembly. Stathmin forms a complex with two tubulin dimers [2] in an interaction that is weakened upon stathmin phosphorylation [3]. Stathmin inhibits microtubule polymerization in vitro by sequestering tubulin [2]. MINUS is a $4.7 \mathrm{kDa}$ polypeptide which inhibits in vitro and in vivo microtubule nucleation and is inactivated by dephosphorylation [4]. Tubulin-folding cofactor D participates in tubulin heterodimer formation through a step involving the hydrolysis of GTP on $\beta$-tubulin [5]. This latter reaction is implicated in the regulation of microtubule dynamics by modulating the availability of GTP-bound heterodimers [6]. Accordingly, the overexpression of cofactor D leads to a complete disassembly of microtubules [7].

The protein EB1 is localized at the distal tips of microtubules and promotes microtubule polymerization in vertebrate cells [8]. It has been suggested that it could also stimulate in vitro microtubule assembly [9], and it has been described as a protein that binds directly to tubulin dimers $[10,11]$. CRMP-2 is expressed in the developing nervous system, and is crucial for establishing and maintaining neuronal polarity. Cypin, a guanine deaminase, regulates dendrite patterning. Both proteins share a region of homology to CRMP that binds directly to tubulin heterodimers, and both promote microtubule assembly $[12,13]$.

Here we have tested whether the known tubulin-dimer binding proteins represented a small proportion of a large group, and whether many other proteins could be identified using systematic approaches. To do this we used chromatography columns containing native tubulin dimers and 
proteomics. These columns were used to analyse a variety of cell extracts. We found a limited number of new tubulin-interacting proteins. 


\section{Materials and Methods}

\section{Preparation of tubulin}

Tubulin purification from bovine brain and preparation of GTP-tubulin complexes was performed as described [14]. To obtain GDP-tubulin, microtubules were assembled at $37^{\circ} \mathrm{C}$ during 20 min from pure tubulin $(100 \mu \mathrm{M})$ in the presence of $1 \mathrm{mM}$ GTP in a PEM buffer (100 mM Pipes, 1 mM EGTA, 1 $\mathrm{mM} \mathrm{MgCl} 2$ ) with $5 \mathrm{mM} \mathrm{MgCl}_{2}$ and 30\% glycerol. Then microtubules were centrifuged at 100,000 g during 45 min at $37^{\circ} \mathrm{C}$, v:v on a cushion containing PEM buffer with $60 \%$ glycerol. GDP-tubulin dimers were obtained after dilution of the microtubule pellet in PEM buffer at $4^{\circ} \mathrm{C}$.

\section{Immunoaffinity column}

A modification of an immunoadsorption procedure described in [15] was used to isolate proteins binding to tubulin dimer. The immunoadsorbent gel was prepared by covalently coupling the rat monoclonal antibody YL1/2 [16]. This antibody reacts specifically with the carboxy-terminus of tyrosinated $\alpha$-tubulin. Pure tubulin was maximally tyrosinated [15] and was loaded onto the column of immobilized YL1/2 antibody. We routinely load $4 \mathrm{mg}$ of maximally tyrosinated tubulin onto a $300 \mu \mathrm{l}$ column. After $10 \mathrm{~min}$, the column was washed with 20 volumes of PEM buffer containing $0.1 \mathrm{M} \mathrm{NaCl}$ to eliminate non tyrosinatable tubulin, followed by 5 volumes of PEM buffer. Then cell extracts (600 $\mu \mathrm{l}$ at $20-25 \mathrm{mg} / \mathrm{ml}$ ) were loaded onto the column and let in contact with the gel for $15 \mathrm{~min}$. The column was then extensively washed with 40 volumes of PEM buffer. Proteins adsorbed on YL1/2 antibody were eluted with 10 volumes of PEM buffer containing a competing peptide (74 $\mu \mathrm{M}$; named V12 peptide) which sequence matches the 12 carboxy-terminal amino-acids of tyrosinated tubulin. Eluted fractions (300 $\mu \mathrm{l}$ each) were collected and analyzed on sodium dodecyl sulfate polyacrylamide gel electrophoresis (SDS-PAGE). Finally, protein bands from the most concentrated fraction (generally the third fraction) were excised from the gel and identified by mass spectrometry. To ascertain the absence of polymerized tubulin in samples, we performed all steps of chromatography at $4^{\circ} \mathrm{C}$. 


\section{Preparation of cell extracts}

HeLa cell extracts: HeLa S3 cells were grown in suspension cultures. Cell suspension was centrifuged at $325 \mathrm{~g}$ during $5 \mathrm{~min}$ at $20^{\circ} \mathrm{C}$. The pellet was washed in PBS, lysed in $1 \mathrm{ml}$ of cold lysis buffer (PEM buffer containing $0.5 \%$ Triton X-100 and protease inhibitors as above) for $10^{8}$ cells. After $15 \mathrm{~min}$ incubation on ice with stirring, lysed cells were centrifuged at $4{ }^{\circ} \mathrm{C}$ during $20 \mathrm{~min}$ at $200,000 \mathrm{~g}$. Supernatant was collected and samples were stored in liquid nitrogen.

HeLa cells synchronization: HeLa S3 were synchronised in M phase by a $19 \mathrm{hr}$-treatment with $0.3 \mu \mathrm{M}$ nocodazole. Synchronisation was controlled by flow cytometry analysis.

Microtubules and associated proteins were removed from cell extracts. For this, microtubules were assembled in cell extracts at $35^{\circ} \mathrm{C}$ during 30 min in the presence of PEM buffer containing Paclitaxel $(20 \mu \mathrm{M}), \mathrm{MgCl}_{2}(5 \mathrm{mM})$ and GTP $(1 \mathrm{mM})$. Then, microtubules were centrifuged at $20^{\circ} \mathrm{C}$ during 45 min at 55,000g. Microtubule free supernatant was collected and stored in liquid nitrogen.

\section{Mass spectrometry and protein identification}

Tubulin-associated proteins were resolved by one-dimensional polyacrylamide gel electrophoresis and stained with Coomassie. Discrete bands were excised from the Coomassie blue-stained gel. The in-gel digestion was carried out as previously described [17]. Gel pieces were then extracted with $5 \%$ [v/v] formic acid solution and acetonitrile. After drying tryptic peptides were resuspended in $0.5 \%$ aqueous trifluoroacetic acid. The samples were injected into a LC-Packings (Dionex) nanoLC (nanoflow liquid chromatography) system and first preconcentrated on a $300 \mu \mathrm{m}$ X 5 mm PepMap C18 precolumn. The peptides were then eluted onto a C18 column $(75 \mu \mathrm{m}$ X $150 \mathrm{~mm})$. The chromatographic separation used a gradient from solution A (5\% acetonitrile: $95 \%$ water: $0.1 \%$ formic acid) to solution B (5\% water : $95 \%$ acetonitrile : $0.1 \%$ formic acid) over $60 \mathrm{~min}$ at a flow rate of $200 \mathrm{nl} / \mathrm{min}$. The LC system was directly coupled to a QTOF Ultima mass spectrometer (Waters). MS/MS (tandem mass spectrometry) data were acquired and processed automatically using MassLynx 3.5 software. Database searching was carried out using the MASCOT 1.7 program available intranet. Two protein databases were used; an updated compilation of SwissProt and Trembl (ftp://us.expasy.org/databases/sp_tr_nrdb/) and the AGI protein database 
(ftp://ftp.arabidopsis.org/home/tair/Sequences/blast_datasets/). Proteins, which were identified with at least 2 peptides showing both a score higher than 40, were validated without any manual validation. For proteins identified by only 1 peptide having a score higher than 40 , the peptide sequence was checked manually. Peptides, with scores higher than 20 and lower than 40, were systematically checked and/or interpreted manually to confirm or cancel the MASCOT suggestion.

\section{Density gradient fractionation}

Sucrose gradients were centrifuged at $80,000 \mathrm{~g}$ for $16 \mathrm{hrs}$ or $32 \mathrm{hrs}$ at $4^{\circ} \mathrm{C}$. Fractions (200 $\left.\mu \mathrm{l}\right)$ were collected manually from the top of the tube and analyzed on SDS-PAGE.

\section{Materials}

HSC70 protein was a generous gift from Dr M. Ladjimi. Construct of EB1 protein with histidin tag was a generous gift of Drs S. Rybina and E. Karsenti. The monoclonal tubulin antibody YL1/2 was a generous gift of Dr. J.V. Kilmartin. 


\section{Results}

\section{Isolation of tubulin dimer associated proteins}

Tubulin affinity chromatography was used to purify tubulin dimer binding proteins from cell and brain extracts. The protocol is schematically depicted on Fig. 1.

We used a competing peptide (V12 peptide) to elute proteins absorbed onto the affinity column. We verified that this modified procedure allowed a good recovery of tubulin. For this, $8 \mathrm{mg}$ of tubulin were loaded onto $600 \mu \mathrm{l}$-column coupled to YL1/2 antibody. After washings, the column was eluted by V12 peptide. Microtubule assembly from eluted tubulin (elution fraction 3, $9.5 \mu \mathrm{M}$ ) demonstrated that tubulin was not denatured by chromatography process (Fig. 2).

We used different experimental conditions for the characterization of the tubulin dimer binding proteome, modifying either the tubulin bound to the column or the cellular extract loaded onto the column.

It is believed that tubulin can exist in two distinctive conformations, a GTP conformation and a GDP conformation [18]. Tubulin with the GTP conformation assembles into microtubules. The GTP hydrolysis occurs upon assembly, which gives rise after microtubule disassembly to GDP-tubulin complexes unable to polymerize. Both tubulin complexes could bind different sets of proteins in the cell cytoplasm. In an attempt to identify such different proteins, tubulin either in the GTP conformation (named GTP-tubulin) or in the GDP conformation (named GDP-tubulin) was loaded on the chromatography column (Fig. 1, step 2).

HeLa cell lysates, interphasic or blocked in G2/M phase were assayed for their content of tubulin binding proteins (Fig. 1, step 3). Proteins associated to microtubules and not to soluble tubulin were removed before chromatographic procedure. This was obtained by an initial assembly of tubulin present in the extracts, followed by a sedimentation of the microtubules by ultracentrifugation. The supernatant, free of microtubules and of microtubule associated proteins, was then loaded onto the column. Cell lysates were loaded onto several tubulin-YL1/2 columns.

Fig. 3A shows the SDS-PAGE analysis of the fraction eluted after loading of the column with GTP-tubulin then with HeLa cells extracts in which microtubules had been previously removed. This gel was cut in 8 large bands and entirely analyzed in mass spectrometry using LC-MSMS. In addition 
to the normal occurrence of $\alpha$ and $\beta$ - tubulin, fourteen other proteins were identified (Table 1 ). No significative difference could be detected in the elution profiles obtained after the pre-loading of the column with GDP-tubulin instead of GTP-tubulin (not shown).

Fig. 2B shows the SDS-PAGE analysis of the fraction eluted after loading of the column with HeLa cell extracts synchronized in G2/M phase. Nine major bands were cut and analyzed by LCMSMS method. Ten proteins could be identified from these bands (Table 1).

The identified tubulin associated proteins can be classed in 4 groups (Table 2): 1) proteins with previously described tubulin dimer association; 2) TOGp, a protein previously described as MAP; 3) heat shock proteins and co-chaperones, mainly HSP90 and HSP70 protein families; 4) proteins that were not shown previously to bind tubulin dimer or microtubules, detected only in mitotic HeLa cells.

Finally, several proteins found in eluted solutions share the same epitope or have strong homologies with the tyrosinated $\alpha$-tubulin C-terminus: EB1 (C-terminus: EEY); CaCyBP, Niban-like protein (C-terminus: EF); RNR2 [19]. Probably these proteins have been isolated during our procedure because they directly react with YL1/2 antibody.

\section{2- EB1 does not bind tubulin dimer}

We tested the direct binding of EB1 to YL1/2 antibody. For this, $100 \mu \mathrm{l}$ of a solution containing EB1 at $80 \mu \mathrm{M}$ was load onto YL1/2 coupled column. After washings, the column was eluted and EB1 was found elution fractions (not shown).

EB1 belongs to a protein family involved in the regulation of microtubule dynamics [20]. There is some experimental evidence that EB1 binds tubulin [11], thus it was possible that the interaction of EB1 with YL1/2 antibody hid its association with tubulin.

We used sucrose gradient centrifugation to test whether EB1 directly binds to the tubulin dimer. To do this, we used native GTP-tubulin and an EB1 construct containing an histidin tag in Nterminus. This construct had been previously tested and the protein remained active with the histidin tag (A. Popov, personal communication). GTP-tubulin was loaded at the top of a sucrose gradient. In case of a weak interaction between the 2 proteins, it could be hypothesized that the complex could dissociate during sedimentation. To prevent this dissociation, EB1 was included in the whole gradient 
before centrifugation. Fig. 4 shows that whether EB1 was present or not, tubulin sedimented at the same level. We tested if the GTP versus GDP-tubulin status could influence EB1 binding. We thus deposite GDP-tubulin at the top of the gradient and sedimented with EB1 in similar conditions. No modification of the sedimentation behavior of tubulin was observed (not shown).

We conclude that there is no association between EB1 and tubulin dimer.

\section{3- HSC70 does not bind native tubulin dimers}

Several studies have indicated a possible interaction between $70 \mathrm{kDa}$-heat shock protein family and microtubule dynamics [21, 22]. As we found HSC70 in the eluted fractions from both HeLa and rat brain extracts (Fig. 3, Table 1), we tested the direct interaction of HSC70 with tubulin dimer using a sedimentation assay. In control experiment, GTP-tubulin or HSC70 were loaded at the top of a separate continuous $5-20 \%$ sucrose gradients and centrifuged. Tubulin peak was found in fraction 12 (Fig. 5A) and HSC70 peak in fraction 9 (Fig. 5B). Then we tested if HSC70 and tubulin could cosediment by loading both of them on the top of the gel (Fig. 5C). We found no difference in HSP70 sedimentation whether the protein was centrifuged alone, or with tubulin (Fig. 5D), demonstrating that there was no detectable stable association between tubulin and HSC70. In another experiment, HSC70 was loaded in the whole gradient before centrifugation. No shift was observed in tubulin peak after centrifugation (not shown). The use of GDP-tubulin instead of GTP-tubulin did not modify these results.

HSC70 binds tightly to ATP and ADP. The nucleotide is bound to the N-terminal domain of HSC70 and used to drive conformational changes in the C-terminal peptide binding domain that alters its affinity for substrates [23]. In order to test a potential interaction of both nucleotide-bound forms of HSC70 with tubulin, ATP $(0.5 \mathrm{mM})$ or ADP $(0.5 \mathrm{mM})$ were added to the gradient before centrifugation. HSC70 and tubulin peak did not move after centrifugation (not shown).

These results show that, under these conditions, we could not detect any association between HSC70 and native tubulin dimer.

The possible association of HSC70 with microtubules was also investigated. To do this, tubulin $(10 \mu \mathrm{M})$ was assembled in the presence of HSC70 $(50 \mu \mathrm{M})$ in a microtubule stabilizing buffer 
containing PEM buffer with taxol (2mM), glycerol (20\%), $\mathrm{MgCl}_{2}(5 \mathrm{mM})$, GTP (1mM) and ATP $(1 \mathrm{mM})$, during $30 \mathrm{~min}$. Then microtubules were centrifuged at $100000 \mathrm{~g}$ during $1 \mathrm{hr}$ at $30^{\circ} \mathrm{C}$. Supernatant and pellet were collected and analyzed on SDS-PAGE. Fig. 5D shows that HSC70 was found in the supernatant in the absence or in the presence of microtubules, demonstrating that there was no association between HSC70 and microtubules. 


\section{Discussion}

In this study, we identified tubulin heterodimer-binding proteins, using an affinity chromatography method followed by mass spectrometry detection.

Our method allowed keeping tubulin in its native form. Indeed, tubulin eluted using the above conditions remained functional and could assemble into microtubules in standard conditions. The Cterminus of $\alpha$-tubulin bound YL1/2 in the chromatography column. Therefore, proteins associated with this part of tubulin dimer, like CLIP170 [24], were excluded from our screening.

Surprisingly, a limited number of proteins binding to tubulin heterodimer was identified. It could be possible that tubulin binding proteins identification was not totally exhaustive, because some proteins were more represented than others in cell extracts. Actually, tubulin was highly represented because of the chromatography procedure itself. Many isoforms of heat shock proteins were also identified in extracts. Although we used a method allowing detection of several proteins in one single band, it cannot be excluded that proteins in very low concentration would not be detected.

Several detected proteins bound directly YL1/2 antibody through their C-terminal part, as did $\alpha$-tubulin. We do not know at this step whether this similarity is purely coincidental or has functional significance.

Among these proteins, EB1 is an end-binding protein that regulates microtubule dynamics [8]. We did not detect EB1-tubulin interaction using sucrose gradient centrifugation, contrary to previous results [11] using co-immunoprecipitation assay with EB1 and tubulin. Although the reason of this discrepancies could come from experimental differences, our result indicates that either tubulin-EB1 binding is weak and transitory, or it is indirect.

Numerous heat shock proteins and co-chaperones were also identified among eluted proteins in all our experiments. The 2 major protein bands corresponded to HSP90 and HSP/HSC70. It has been shown that HSP90 inhibits in vitro microtubule assembly [25]. Several studies have described a colocalization of HSP/HSC70 with microtubules, and suggested a direct effect of these proteins on microtubule dynamics, although the matter is still debated (for a review, see [21]). However, we show using sedimentation assay that there is no direct association between HSC70 and tubulin dimer or microtubules. This is not in accordance with previous published results showing binding between 
HSP70 and microtubules [26]. A possible explanation of such a discrepancy is that HSC70 and HSP70 do not interact similarly with tubulin.

The presence of HSC70 in eluted fractions after chromatography process could have several explanations. If some tubulin molecules adsorbed on the column were degraded, HSC70 could function as a chaperone and bind degraded molecules. However, we checked that assembly properties of tubulin were not altered after elution, showing that there was no detectable tubulin degradation (Fig. 2). Alternatively, HSC70 could bind tubulin indirectly, through multiprotein complex with cochaperones, several of them being detected in eluted fractions. Two other proteins associated to HSC70 were also found after elution, stathmin and clathrin (Table 2). Stathmin protein forms a complex with tubulin [27] and stimulates microtubule disassembly [28]. The interaction between stathmin and HSC70 has been shown using immunoprecipitation in PC12 cells [29]. HSC70 is involved in multiprotein complexes associated in the uncoating of clathrin-coated vesicles [30].

In addition to clathrin, four other proteins found in fractions eluted after mitotic cells loading have not been described as tubulin binding protein or microtubule associated protein. They were APC2, importin $\alpha$ and $\beta$, and LRP130 (Table 1). Interestingly, the 3 first proteins have been shown to be implicated in mitotic spindle control. APC2 is a member of the Anaphase-Promoting Complex (APC), a large ubiquitin-protein ligase complex [31]. The microtubule associated protein Ase and the kinesin motor protein Kip1 have been found to be substrates of APC in budding yeast and play a role in regulating the mitotic spindle [32, 33].

The nuclear import receptors, $\alpha$ and $\beta$ importins, directly regulate the activities of at least 2 microtubule organizing components during mitosis, TPX2 [34] and NuMA [35] respectively.

LRP-130 is a RNA-binding protein, and its biological function is currently suggested to be implicated in mRNA metabolism in both nucleus and mitochondria [36]. Proteins that function in translation have been reported to bind to the cytoskeleton. This association could serve as a mechanism to regulate translation rate or to increase efficiency of translation [37].

To our knowledge, this study represents the first systematic identification of proteins binding to tubulin dimer in its native form. Other methods will be required to determine if some of these 
proteins associate directly or indirectly with tubulin dimer by interacting with other proteins, as a component of a protein complex. 
Acknowledgments: This work was supported by grants from La Ligue Nationale Contre le Cancer (“équipe labellisée Ligue”). 


\section{References}

[1] O. Valiron, N. Caudron, D. Job, Microtubule dynamics, CMLS 58 (2001) 2069-2084.

[2] L. Jourdain, P. Curmi, A. Sobel, D. Pantaloni, M.F. Carlier, Stathmin: a tubulin-sequestering protein which forms a ternary T2S complex with two tubulin molecules, Biochemistry 36 (1997) 10817-108121.

[3] M.O. Steinmetz, W. Jahnke, H. Towbin, C. Garcia-Echeverria, H. Voshol, D. Muller, J. van Oostrum, Phosphorylation dirupts the central helix in Op18/stathmin and suppresses binding to tubulin, EMBO Rep. 2 (2001) 505-510.

[4] P. Fanara, B. Oback, K. Ashman, A. Podtelejnikov, R. Brandt, Identification of MINUS, a small polypeptide that functions as a microtubule nucleation suppressor, EMBO J. 18 (1999) 565-577.

[5] G. Tian, S.A. Lewis, B. Feierbach, T. Stearns, H. Rommelaere, C. Ampe, N.J. Cowan, Tubulin subunits exist in an activated conformational state generated and maintained by proteins cofactors, J. Cell Biol. 138 (1997) 821-832.

[6] G. Tian, A. Bhamidipati, N.J. Cowan, S.A. Lewis, Tubulin folding cofactors as GTPase-activating proteins. GTP hydrolysis and the assembly of the alpha/beta-tubulin heterodimer, J. Biol. Chem. 274 (1999) 24054-24058.

[7] A. Bhamidipati, S.A. Lewis, N.J. Cowan, ADP ribosylation factor-like protein 2 (Arl2) regulates the interaction of tubulin-folding cofactor D with native tubulin, J. Cell Biol. 149 (2000) 1087-1096.

[8] J.S. Tirnauer, B.E. Bierer, EB1 proteins regulate microtubule dynamics, cell polarity, and chromosome stability, J. Cell Biol. 149 (2000) 761-766.

[9] L.A. Ligon, S.S. Shelly, M. Tokito, E.L.F. Holzbaur, The microtubule plus-end proteins EB1 and dynactin have differential effects on microtubule polymerization, Mol. Biol. Cell 14 (2003) 14051417.

[10] K. Schwartz, K. Richards, D. Bostein, BIM1 encodes a microtubule-binding protein in yeast, Mol. Biol. Cell. 8 (1997) 2677-2691. 
[11] J.P. Juwana, P. Henderikx, A. Misho, A. Wadle, N. Fadle, K. Gerlach, J.W. Arends, H. Hoogenboom, M. Pfreundschuh, C. Renner, EB/RP gene family encodes tubulin binding proteins, Int. J. Cancer 81 (1999) 275-284.

[12] Y. Fukata, T.J. Itoh, T. Kimura, C. Ménager, T. Nishimura, T. Shiromizu, H. Watanabe, N. Inagaki, A. Iwamatsu, H. Hotani, K. Kaibuchi, CRMP-2 binds to tubulin heterodimers to promote microtubule assembly, Nat. Cell Biol. 4 (200) 583-591.

[13] B.F. Akum, M. Chen, S.I. Gundrson, G.M. Riefler, M.M. Scerri-Hansen, B.L. Firestein, Cypin regulates dendrite patterning in hippocampal neurons by promoting microtubule assembly, Nat. Neurol. 7 (2004) 145-152.

[14] N. Caudron, O. Valiron, Y. Usson, P. Valiron, D. Job, A reassessment of the factors affecting microtubule assembly and disassembly in vitro, J. Mol. Biol. 297 (2000) 211-220.

[15] L. Paturle, J. Wehland, R.L. Margolis, D. Job, Complete separation of tyrosinated, detyrosinated, and nontyrosinatable brain tubulin subpopulations using affinity chromatography, Biochemistry 28 (1989) 2698-2704.

[16] J. Wehland, M.C. Willigham, J.V. Sandoval, A rat monoclonal antibody reacting specifically with the tyrosinated form of alpha-tubulin. I. Biochemical characterization, effects on microtubule polymerization in vitro, and microtubule polymerization and organization in vivo, J. Cell Biol. 97 (1983) 1467-1475.

[17] M. Ferro, D. Salvi, S. Brugière, D. Miras, S. Kowalski, M. Louwagie, J. Garin, J. Joyard, N. Rolland, Proteomics of the chloroplast envelope membranes from Arabidopsis thaliana, Mol. Cell. Proteomics 2 (2003) 325-45

[18] E. Nogales, H.W. Wang, H. Niederstrasser, Tubulin rings: which way do they curve ? Curr. Opin. Struct. Biol. 13 (2003) 256-261.

[19] N.M. Standart, S.J. Bray, E.L. George, T. Hunt, J.V. Ruderman, The small subunit of ribonucleotide reductase is encoded by one of the most abundant translationally regulated maternal RNAs in clam and sea urchin eggs, J. Cell. Biol. 100 (1985) 1968-1976. 
[20] J.S. Tirnauer, S. Grego, E.D. Salmon, T.J. Mitchison, EB1- microtubule interactions in xenopus egg extracts: role of EB1 in microtubule stabilization and mechanisms of targeting to microtubules, Mol. Biol. Cell 13 (2002) 3614-3626.

[21] P. Liang, T.H. MacRae, Molecular chaperones and the cytoskeleton, J. Cell Sci. 110 (1997) 14311440.

[22] M. Oka, M. Nakai, T. Endo, C.R. Lim, Y. Kimata, K. Kohno, Loss of Hsp70-Hsp40 chaperone activity causes abnormal nuclear distribution and aberrant microtubule formation in M-phase of Saccharomyces cerevisiae, J. Biol. Chem. 273 (1998) 29727-29737.

[23] N. Benaroudj, F. Triniolles, M.M. Ladjimi, Effect of nucleotides, peptides, and unfolded proteins on the self-association of the molecular chaperone HSC70, J. Biol. Chem. 271 (1996) 18471-18476.

[24] A.C. Badin-Larçon, C. Boscheron, J.M. Soleilhac, M. Piel, C. Mann, E. Denarier, A. FourestLieuvin, L. Lafanéchère, M. Bornens, D. Job, Suppression of nuclear oscillations in Saccharomyces cerevisiae expressing Glu tubulin, Proc. Natl. Acad. Sci. USA 101 (2004) 557-5582.

[25] C. Garnier, P. Barbier, R. Gilli, C. Lopez, V. Peyrot, C. Briand, Heat-shock protein 90 (hsp90) binds in vitro to tubulin dimer and inhibits microtubule formation, Biochem. Biophys. Res. Commun. 250 (1998) 414-419.

[26] C. Sanchez, R. Padilla, R. Paciucci, J.C. Zabala, J. Avila, Binding of heat-shock protein 70 (hsp70) to tubulin, Archives of Biochem. and Biophysics 310 (1994) 428-432.

[27] B. Gigant, P.A. Curmi, C. Martin-Barbey, E. Charbaut, S. Lachkar, L. Lebeau, S. Siavoshian, A. Sobel, M. Knossow, The 4 A X-ray structure of a tubulin:stathmin-like domain complex, Cell 102 (2000) 809-816.

[28] L. Belmont, T. Mitchison, H.W. Deacon, Catastrophic revelations about Op18/stathmin, Trends Biochem. Sci. 21 (1996) 197-198.

[29] V. Manceau, O. Gavet, P. Curmi, A. Sobel, Stathmin interaction with HSC70 family proteins, Electrophoresis 20 (1999) 409-417.

[30] E. Ungewickell, H. Ungewickell, S.E. Holstein, R. Lindner, K. Prasad, W. Barouch, B. Martin, L.E. Greene, E. Eisenberg, Role of auxilin in uncoated clathrin-coated vesicles, Nature 378 (1995) 632-635. 
[31] J.W. Harper, J.L. Burton, M.J. Solomon, The anaphase-promoting complex: it's not just for mitosis any more, Genes Dev. 165 (2002) 2179-2206.

[32] Y.L. Juang, J. Huang, J.M. Peters, M.E. Mc Laughlin, C.Y. Tai, D. Pellman, APC-mediated proteolysis of Ase1 and the morphogenesis of the mitotic spindle, Science 275 (1997) 1311-1314.

[33] D.M. Gordon, D.M. Roof, Kip1, a kinesin-related motor protein is a substrate for APC-mediated proteolysis, Mol. Biol. Cell 8 (Suppl.) (1997) 813.

[34] C.A. Schatz, R. Santarella, A. Hoenger, E. Karsenti, I.W. Mattaj, O.J. Gruss, R.E. Carazo-Salas, Importin alpha-regulated nucleation of microtubules by TPX2, EMBO J. 22 (2003) 2060-2070.

[35] M.V. Nachury, T.J. Maresca, W.C. Salmon, C.M. Waterman-Storer, R. Heald, K. Weis, Importin beta is a mitotic target of the small GTPase Ran in spindle assembly, Cell 104 (2001) 95-106.

[36] S. Mili, S. Pinol-Roma, LRP130, a pentatricopeptide motif protein with a noncanonical RNAbinding domain, is bound in vivo to mitochondrial and nuclear RNAs, Mol. Cell. Biol. 23 (2003) $4972-4982$.

[37] R.P. Jansen, RNA-cytoskeletal associations, FASEB J. 13 (1999) 455-466.

[38] A. Sobel, A.H. Tashjian, Distinct patterns of cytoplasmic protein phosphorylation related to regulation of synthesis and release of prolactin by GH cells, J. Biol. Chem. 258 (1983) 10312-10324.

[39] S.A. Lewis, G. Tian, N.J. Cowan, The alpha and beta tubulin folding pathways, Trends Cell. Biol. 7 (1997) 479-485.

[40] S. Charasse, M. Mazel, S. Taviaux, P. Berta, T. Chow, C. Larroque, Characterization of the cDNA and pattern expression of a new gene over-expressed in human hepatomas and colonic tumors, Eur. J. Biochem. 234 (1995) 406-413.

[41] S. Chen, V. Prapapanich, R.A. Rimerman, B. Honoré, D.F. Smith, Interactions of p60, a mediator of progesterone receptor assembly, with heat shock proteins HSP90 and HSP70, Mol. Endocrinol. 10 (1996) 682-693.

[42] C.Y. Fan, S. Lee, D.M. Cyr, Mechanisms for regulation of Hsp70 function by Hsp40, Cell Stress Chaperones 8 (2003) 309-316. 
[43] S. Takayama, Z. Xie, J.C. Reed, An evolutionary conserved family of Hsp70/Hsc70 molecular chaperone regulators, J. Biol. Chem. 274 (1999) 781-786.

[44] A.S. Lee, Mammalian stress response: induction of the glucose-regulated protein family, Curr. Opin. Cell Biol. 4 (1992) 267-273.

[45] B.C. Santos, A. Chevaile, R. Kojima, S.R. Gullans, Characterization of the Hsp110/SSE gene family response to hyperosmolality and other stresses, Am. J. Physiol. 274 (1998) F1054-1061.

[46] S.A. Mousavi, L. Malerod, R. Kjeken, Clathrin-dependent endocytosis, Biochem. J. 377 (2004) 116.

[47] J. Hou, F. Wang, W.F. McKeehan, Molecular cloning and expression of the gene for a major leucine-rich protein from human hepatoblastoma cells (HepG2), In Vitro Cell Dev. Biol. Anim. 30A (1994) 111-114.

[48] K. Weis, Importins and exportins: how to get in and out of the nucleus, Trends Biochem. Sci. 136 (1998) 859-870. 


\section{Figures}

\section{Figure 1:}

Strategy used to isolate and identify proteins associated to tubulin dimers. YL1/2 antibody was covalently coupled to Sepharose 4B gel (step 1); tubulin dimers (step 2) then cell extracts (step 3) were loaded onto the column; protein complexes were eluted using V12 peptide solution (step 4), analyzed by SDS-PAGE and identified using mass spectrometry.

\section{Figure 2:}

Tyrosinated tubulin were loaded onto Sepharose 4B column coupled to YL1/2 (anti-Tyr-tubulin) antibody and eluted (see text). Microtubule assemblies from eluted tubulin $(9.5 \mu \mathrm{M})$ and from control tubulin $(9.5 \mu \mathrm{M})$, at $37^{\circ} \mathrm{C}$ in PEM buffer with $1 \mathrm{mM}$ GTP, followed in a spectrophotometer at $350 \mathrm{~nm}$.

Figure 2: Identification of tubulin associated proteins.

Interphasic (A) or mitotic (B) HeLa cell lysates were subjected to affinity columns. Eluted proteins were subjected to SDS-PAGE analysis (A: $12 \%$ polyacrylamide; B: $10 \%$ polyacrylamide). Analysis of protein bands was performed by mass-spectrometry. Molecular masses of the markers are presented in $\mathrm{kDa}$.

Figure 3: Sucrose density gradient centrifugation of EB1 and tubulin dimer.

Samples of $30 \mu \mathrm{l}$ tubulin $(7 \mu \mathrm{M})$ were subjected to continuous $5-20 \%$ sucrose gradient centrifugation during 16 hrs, in the absence (A) or in the presence of EB1 (50 $\mu \mathrm{M})$ added into the whole gradient (B). After collection, fractions were analyzed on SDS-PAGE. (C) Quantification of tubulin contents in each fractions.

Figure 4: Sucrose density gradient centrifugation of HSC70 and tubulin dimer 
Samples of $30 \mu \mathrm{l}$ tubulin $(7 \mu \mathrm{M})(\mathrm{A})$ or HSC70 $(1.5 \mu \mathrm{M})$ (B) or mix of both proteins (C) were subjected to continuous 5-20\% sucrose gradient centrifugation during 32 hrs. After collection, fractions were analyzed on SDS-PAGE. (D) Quantification of HSC70 contents in each fractions. (E) Tubulin $(10 \mu \mathrm{M})$ was assembled in the presence of HSC70 $(50 \mu \mathrm{M})$ in microtubule stabilizing buffer (see text) and microtubules were centrifuged. Supernatant (S) and pellet (P) were collected and analyzed on SDS-PAGE. 


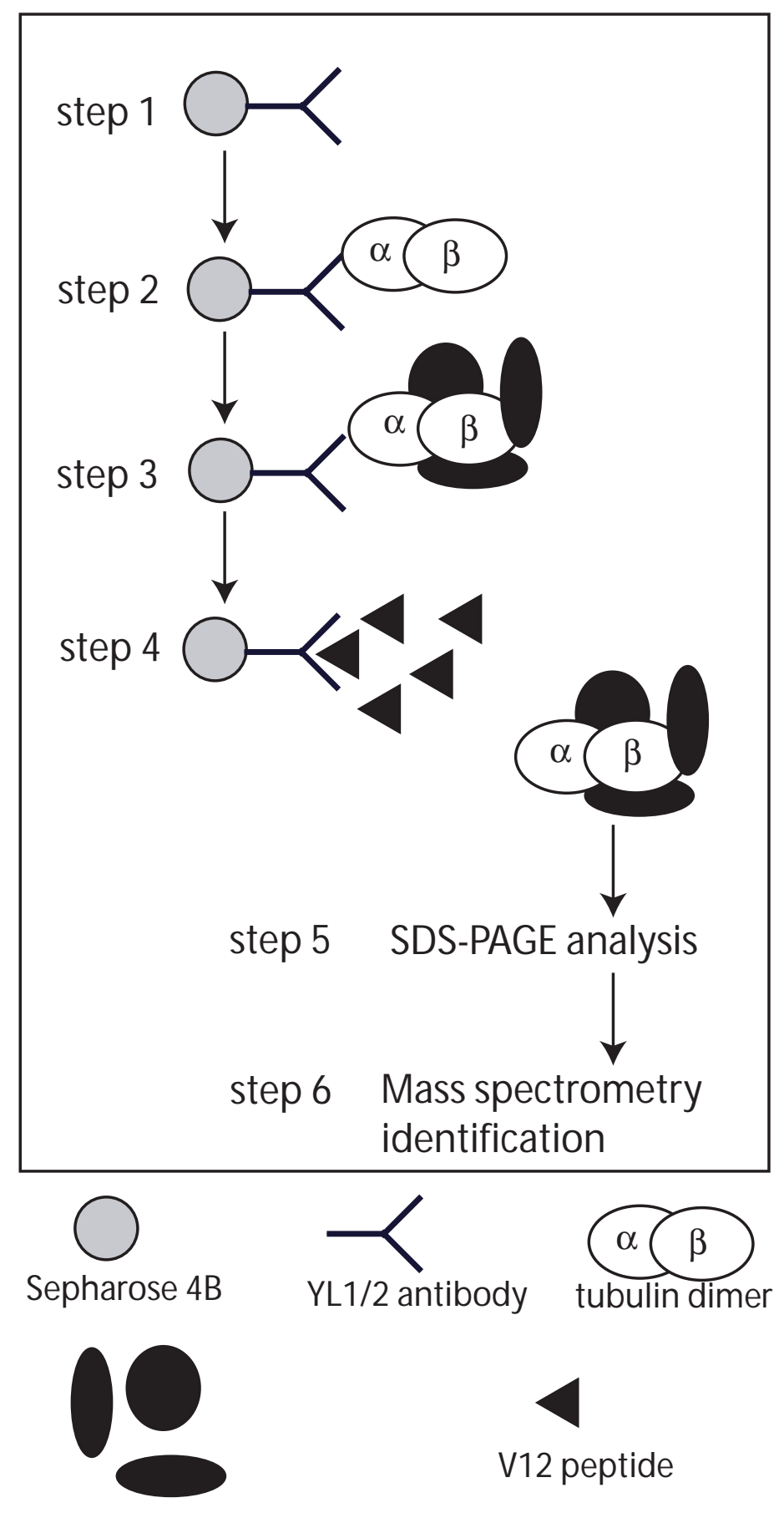

proteins from cell extracts 





A

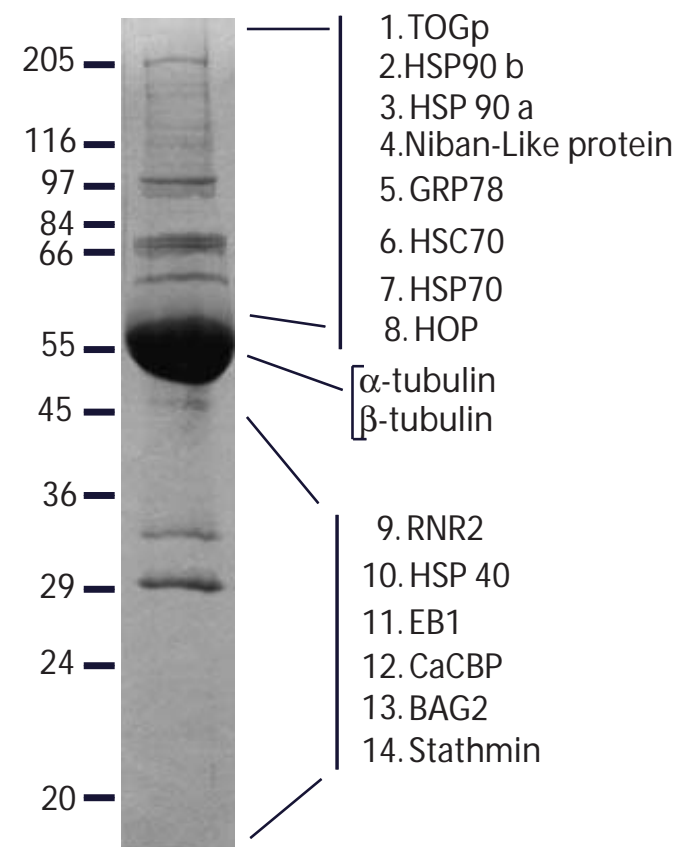

B

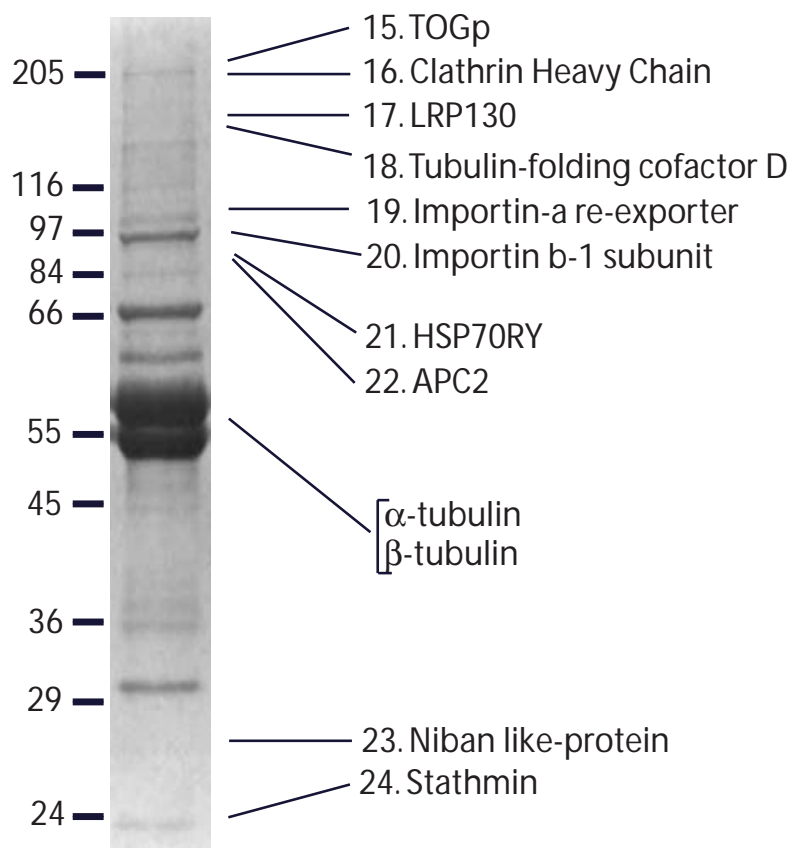








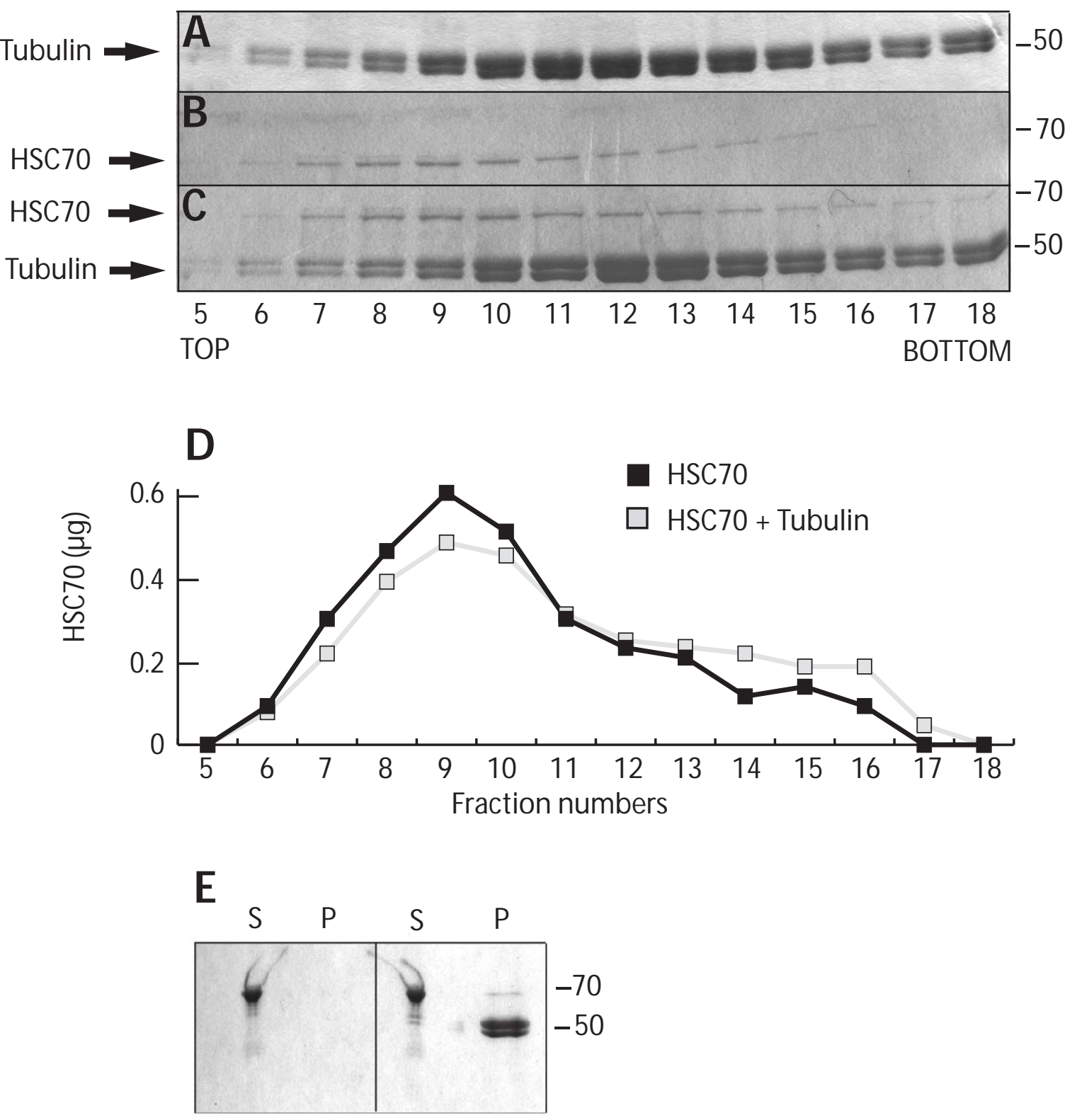
Table 1: Identification of tubulin associated proteins

$\begin{array}{lllll}\text { Number (a) } & \text { Protein name } & \text { Access ion } & \text { Theoretical } & \text { Number of identified } \\ & \text { number } & \text { molecular } & \text { peptides (b) }\end{array}$

1) HeLa cell lysates (interphase, after microtubule removal)

$\begin{array}{ll}1 & \text { TOGp } \\ 2 & \text { HSP90 } \beta \\ 3 & \text { HSP90 } \alpha \\ 4 & \text { Niban-like protein } \\ 5 & \text { GRP78 } \\ 6 & \text { HSC70 } \\ 7 & \text { HSP70 } \\ 8 & \text { HOP (HSC70/HSP90 Organizing Protein) } \\ 9 & \text { Ribonucleotide small chain reductase (RNR2) } \\ 10 & \text { HSP40 } \\ 11 & \text { EB1 }\end{array}$

$\begin{array}{lll}\underline{\mathbf{Q 1 4 0 0 8}} & 225.3 & 3 \\ \underline{\mathbf{P 0 8 2 3 8}} & 84.5 & 11 \\ \underline{\mathbf{P 0 7 9 0 0}} & 83 & 6 \\ \underline{\mathbf{Q 9 6 T A 1}} & 82.6 & 1 \\ \underline{\mathbf{P 1 1 0 2 1}} & 72.3 & 1 \\ \underline{\mathbf{P 1 1 1 4 2}} & 70.8 & 9 \\ \underline{\mathbf{P 0 8 1 0 7}} & 70 & 6 \\ \underline{\mathbf{P 3 1 9 4 8}} & 62.5 & 1 \\ \underline{\mathbf{P 3 1 3 5 0}} & 44.8 & 5 \\ \underline{\mathbf{P 3 1 6 8 9}} & 44.8 & 1 \\ \underline{\mathbf{Q 1 5 6 9 1}} & 30 & 3\end{array}$




\begin{tabular}{|c|c|c|c|c|}
\hline 12 & Calcyclin binding protein (CaCBP) & $\underline{060666}$ & 26.1 & 4 \\
\hline 13 & BAG2 & $\underline{095816}$ & 23.7 & 1 \\
\hline 14 & Stathmin & $\underline{\mathbf{P 1 6 9 4 9}}$ & 17.1 & 1 \\
\hline \multicolumn{5}{|c|}{ 2) HeLa cell lysates (G2/M) } \\
\hline 15 & TOGp & $\underline{\mathbf{Q} 14008}$ & 225.3 & 10 \\
\hline 16 & Clathrin Heavy Chain & $\underline{\mathbf{P} 49951}$ & 191.5 & 10 \\
\hline 17 & 130 kDa leucine rich protein (LRP130) & $\underline{\mathbf{P 4 2 7 0 4}}$ & 145.1 & 1 \\
\hline 18 & Tubulin-folding cofactor D & Q9BTW9 & 132.4 & 3 \\
\hline 19 & Importin $\alpha$ re-exporter & $\underline{\text { P55060 }}$ & 110.2 & 2 \\
\hline 20 & Importin $\beta-1$ subunit & $\underline{\text { Q14974 }}$ & 97 & 1 \\
\hline 21 & HSP70RY & $\underline{\text { P34932 }}$ & 94.2 & 3 \\
\hline 22 & Anaphase promoting complex subunit 2(APC2) & $\underline{\text { Q9UJX6 }}$ & 93.7 & 1 \\
\hline 23 & Niban like protein & Q96TA1 & 82.6 & 2 \\
\hline 24 & Stathmin & $\underline{\mathbf{P 1 6 9 4 9}}$ & 17.1 & 4 \\
\hline
\end{tabular}

(a) Protein number (cf Figure 3); (b) Identified peptides are given as supplemental data. 
Table 2 : Functional categories of tubulin associated proteins

Proteins Localization/Function $\quad$ Identification

(1) Proteins with previously described tubulin dimer association

$\begin{array}{lll}\text { Stathmin } & \text { Stimulates microtubule catastrophes [38] interphase, G2/M } \\ \text { Tubulin-folding cofactor D } & \text { involved in the generation of new tubulin heterodimers [39] }\end{array}$

Tubulin-folding cofactor D ～involved in the generation of new tubulin heterodimers [39] G2/M

(2) $M A P$

TOGp

(3) Heat shock proteins and co-chaperones

$\begin{array}{ll}\text { HSP90 } & \begin{array}{l}\text { Localizes to microtubules (for a review on HSP and microtubules see [21]) interphase } \\ \text { HSP70/HSC70 }\end{array} \\ \text { HOP } & \text { Localizes to microtubules [21] } \\ \text { HSP40 } & \text { HSP70 co-chaperone [42] } \\ \text { BAG2 } & \text { HSP70 and HSC70 co-chaperone [43] interphase } \\ \text { GRP78 } & \text { Localized in the endoplasmic reticulum, HSP70 family [44] interphase }\end{array}$


(4) Proteins not previously described as having tubulin dimer nor microtubule association

Clathrin Heavy Chain

LRP130

APC2

Importin $\alpha$

Importin $\beta$
Responsible of an endocytic pathway [46]

G2/M

Bounds to mitochondrial and nuclear RNAs [47]

Member of the anaphase-promoting complex [31]

G2/M

G2/M

Nuclear import receptors [48]

G2/M

Nuclear import receptors [48] 


\section{Supplemental data}

Identification of tubulin associated proteins using LC-MSMS technique.

Protein name $\quad$ Identified peptides

\section{1) HeLa cell lysates}

TOGp

$\operatorname{HSP90} \alpha$

HSP90 $\beta$

Niban-like protein

GRP78

HSC70

HSP70

HOP

RNR2
EGLAELYEYK- YSDADIEPFLK- EGLDEVAGIINDAK

APFDLFENR-DQVANSAFVER-YYTSASGDEMVSLK-HLEINPDHSIIETLR-NPDDITNEEYGEFYK-

LGLGIDEDDPTADDTSAAVTEEMPPLEGDDDTSR

YIDQEELNK-ADLINNLGTIAK-EQVANSAFVER-ELISNASDALDK-EDQTEYLEER-TLTLVDTGIGMTK-

EGLELPEDEEEK-_GVVDSEDLPLNISR-SLTNDWEDHLAVK-HLEINPDHPIVETLR-YHTSQSGDEMTSLSEYVSR

FQELIFEDFAR

ITPSYVAFTPEGER

LLQDFFNGK-VEIIANDQGNR-FEELNADLFR-NSLESYAFNMK-RFDDAVVQSDMK-SQIHDIVLVGGSTR-

TTPSYVAFTDTER-_SFYPEEVSSMVLTK-TVTNAVVTVPAYFNDSQR

DAGVIAGLNVLR-LVNHFVEEFK-AQIHDLVLVGGSTR-IINEPTAAAIAYGLDR

LAYINPDLALEEK

QYIEFVADR-_IEQEFLTEALPVK-_FSQEVQITEAR-_GLSLVDKENTPPALSGTR-_HLVHKPSEER 
HSP40

EB1

CaCBP

BAG2

Stathmin

\section{2) HeLa cell lysates (G2/M)}

TOGp

Clathrin Heavy Chain

\section{LRP130}

Tubulin-folding cofactor D

Importin $\alpha$ re-exporter

Importin $\beta-1$ subunit

HSP70RY

APC2
QISQAYEVLSDAK

KNPGVGNGDDEAAELMQQVNVLK-QGQETAVAPSLVAPALNKPK-KPLTSSSAAPQR

ASEELQKDLEEVK-SYSMIVNNLLKPISVEGSSK-AELLDNEKPAAVVAPITTGYTVK-EKPSYDTETDPSEGLMNVLK

\section{LLESLDQLELR}

DLSLEEIQK

TEISDKITSELVSK-EGLDEVAGIINDAK-AQNISSNANMLR-DAAFEALGTALK-TALAATNPAVR-YSDADIEPFLK-

FVTDSNAVVQLK-HINDSAPEVR-TTGEVVSGVVSK-LEAGDYADLVK

NNLAGAEELFAR-IYIDSNNNPER-IVLDNSVFSEHR-RPISADSAIMNPASK-KFNALFAQGNYSEAAK-

TSIDAYDNFDNISLAQR-_LASTLVHLGEYQAAVDGAR-LAELEEFINGPNNAHIQQVGDR-

AIQFYLEFKPLLLNDLLMVLSPR-RPLIDQVVQTALSETQDPEEVSVTVK

GFTLNDAANSR

LQQVLTGLR-AASAAFQENVGR-AVTHTSPEDVSFAESR

FLESVEGNQNYPLLLLTLLEK-SFSLLQEAIIPYIPTLITQLTQK

SSAYESLMEIVK

AFSDPFVEAEK-VLATAFDTTLGGR-AGGIETIANEYSDR

DQQLVYSAGVYR 
